\title{
Rancang Bangun Manfaat Sistem Informasi Pelayanan Berbasis Website Pada Rukun Warga 005 Kapuk Jakarta Barat
}

\author{
Fefbyanto Saputro $^{\mathrm{a} 1}$, Esron Rikardo Nainggolan ${ }^{\mathrm{a} 2}$ \\ ${ }^{a}$ STMIK Nusa Mandiri \\ Jl. Jatiwaringin No. 2, Cipinang Melayu, Makasar Jakarta Timur \\ 1 fefbyant1602@nusamandiri.ac.id \\ 2esron.ekg@nusamandiri.ac.id
}

\begin{abstract}
Abstrak
Rukun Tetangga dan Rukun Warga merupakan bagian dari penyelenggaraan dalam Pemerintah Desa atau Kelurahan. Rukun Tetangga (RT) dibentuk melalui musyawarah masyarakat setempat, sedangkan Rukun Warga (RW) dibentuk melalui musyawarah pengurus Rukun Tetangga diwilayah tertentu dalam rangka memberikan pelayanan pemerintah dan masyarakat. Dalam pelayanan publik pada RT dan RW. 005 mempunyai kendala dalam penyampaian informasi sehingga masyarakat mengalami kesulitan dalam memperoleh informasi seputar berita, kegiatan warga, iuran warga, dan persyaratan yang dibutuhkan untuk mengajukan surat pengantar menggunakan tulisan tangan dan juga tersimpan dalam bentuk buku agenda. Dengan Analisa yang digambarkan dengan menggunakan model bahasa UML (Unified Modelling Language) sehingga terbentuknya sebuah sistem berbasis website yang dapat diakses oleh semua masyarakat yang merupakan solusi tepat untuk sistem informasi pelayanan RT dan RW
\end{abstract}

Kata kunci: RT, RW, Sistem Informasi, Website

\section{Design and Build Benefits of Service Information System Based Website for Citizens Assosiation 005 Kapuk West Jakarta}

\begin{abstract}
Neighborhood harmony and Citizen harmony are part of the implementation in the village or village Government. Neighborhood harmony (RT) was formed through the deliberation of the local community, meanwhile, Citizen harmony (RW) is formed through the deliberation of Neighborhood Association in certain areas to provide government and community services. In public services on RT and RW. 005 Kapuk obstacles in the delivery of information so that people have difficulty in obtaining information about news, citizen activities, citizen contributions, and the requirements needed to submit a letter of introduction using handwriting and also stored in the form of an agenda book. With the analysis described using the UML language model (Unified Modeling Language) so that the formation of a website-based system that can be accessed by all people is the right solution for RT and RW service information systems.
\end{abstract}

Keywords: RT, RW, Information System, Website

\section{Pendahuluan}

Kemajuan teknologi informasi sekarang semakin cepat berkembang dan mudah diakses dari kalangan masyarakat, bangsa dan Negara. Dengan perkembangan dan kemajuan ilmu pengetahuan, teknologi informasi sangat mudah didapatkan. Dalam kehidupan saat ini, teknologi informasi tidak dapat dipisahkan dari para pengguna teknologi internet yang semakin canggih. Maka untuk mendapatkan sebuah informasi dari internet sangat cepat dan tepat [1]. Dengan perkembangan dan kemajuan teknologi yang semakin canggih, untuk mendapatkan berbagai macam informasi sangatlah mudah. Dengan adanya teknologi informasi melalui media online, pengguna teknologi dapat dengan cepat mencari atau menemukan informasi yang dibutuhkan [1]. Salah satu perkembangan teknologi yang menggunakan media website memberikan kemajuan dalam dunia teknologi. Untuk menyampaikan informasi melalui media website, pengguna dapat dengan mudah mendapatkan informasi serta memperluas jaringan informasi dan komunikasi [1].

Website merupakan bagian dari WWW atau

(World Wide Web) di internet. Berdasarkan teknologi, website dibagi menjadi dua yaitu bersifat statis dan bersifat dinamis. Dalam website statis berisi informasi tetap yang jarang diperbarui, sedangkan website dinamis berisi informasi yang selalu dapat diperbarui [2]. Dalam sistem informasi media website, suatu organisasi dapat dengan mudah menyediakan sekumpulan informasi. Dengan adanya sistem informasi memberikan kemudahan 
untuk pengguna mengetahui informasi yang dibutuhkan. Rukun Tetangga dan Rukun Warga merupakan bagian dari penyelenggaraan dalam Pemerintahan Desa. Rukun Warga dibentuk melalui musyawarah Rukun Tetangga, sedangkan Rukun Tetangga dibentuk melalui musyawarah masyarakat dalam suatu wilayah [3]. Dalam menjalankan tugas dari pemerintah desa, RT/RW mempunyai fungsi memudahkan pelayanan administrasi, surat-menyurat, informasi seputar berita, manajemen iuran, kerukunan antar warga, serta ketertiban dan keamanan warga setempat. Suatu organisasi pelayanan Rukun Tetangga dan Rukun Warga yang tidak menyediakan informasi, menyebabkan permasalahan yang terjadi. Contohnya seperti pelayanan informasi Rukun Tetangga dan Rukun Warga 005 Kapuk Jakarta Barat. Permasalahan RT/RW saat ini masih menggunakan tulisan tangan dalam bentuk surat-menyurat serta pengarsipan data penduduk dalam bentuk buku agenda yang tersimpan. Dalam arsip pendataan kependudukan warga masih menggunakan buku induk mempersulit pencarian pendataan warga [1] Dengan adanya permasalahan yang terjadi dalam pelayanan Rukun Tetangga dan Rukun Warga 005 Kapuk. Dengan menggunakan media website sistem informasi masyarakat warga dapat dengan mudah menemukan informasi yang dibutuhkan serta mengurangi dan meringankan permasalahan warga RT/RW005 Kapuk.

Permasalahan pengelolaan dan penyimpanan data penduduk yang masih menggunakan buku agenda manual, sehingga bisa hilang, kebakar ataupun terkena banjir. Masyarakat warga RT/RW005 mengalami kesulitan memperoleh informasi seputar berita, kegiatan warga, iuran warga, dan persyaratan yang dibutuhkan untuk mengajukan surat pengantar. Dibutuhkan suatu sistem informasi untuk mempermudah warga dalam mengetahui kegiatan warga, iuran warga, serta proses surat-menyurat yang sebelumnya menggunakan tulis tangan.

Berdasarkan identifikasi permasalahan yang terjadi sebagai berikut:

1. Pengelolaan dan penyimpanan data penduduk yang masih menggunakan buku agenda manual, sehingga bisa hilang, kebakar ataupun terkena banjir.

2. Masyarakat warga RT/RW005 mengalami kesulitan memperoleh informasi seputar berita, kegiatan warga, iuran warga, dan persyaratan yang dibutuhkan untuk mengajukan surat pengantar.

3. Dibutuhkan suatu sistem informasi untuk mempermudah warga dalam mengetahui kegiatan warga, iuran warga, serta proses surat-menyurat yang sebelumnya menggunakan tulis tangan.

Dengan merumuskan masalah sebagai berikut:

1. Bagaimana mengelola dan menyimpan data penduduk secara efektif dan efisien?

2. Bagaimana merancang suatu sistem informasi berbasis online yang dapat diakses dengan mudah untuk kebutuhan warga?

3. Bagaimana implementasi suatu sistem informsi yang memudahkan warga untuk mendapatkan informasi tanpa mengurangi silaturahmi kerukunan antar warga.
Berdasarkan permasalahan yang terjadi dengan bertujuan sebagai berikut:

1. Untuk mengelola dan menyimpan arsip data penduduk, penulis melakukan perekapan data dengan perangkat lunak dalam bentuk Softcopy.

2. Untuk merancang suatu sistem informasi yang dapat diakses dengan mudah penulis merancang sebuah website informasi agar warga dapat mengetahui informasi yang dibutuhkan.

Dengan adanya inovasi sistem informasi pelayanan berbasis website, diharapkan warga dengan mudah mendapatkan informasi dalam hal pendataan warga maupun dalam hal kegiatan seputar warga.

\section{Metode PenElitian}

Pada penelitian ini dilakukan dengan tahapan sebaai berikut:

\section{A. Teknik Pengumpulan Data}

1) Observasi(Observation): Tahap observasi melakukan pengamatan dan kunjungan untuk mengetahui kegiatan warga, pendataan kependudukan, mengelola iuran warga, serta proses pembuatan surat-menyurat untuk warga RW.005 Kapuk Jakarta Barat.

2) Wawancara(Interview): Dalam tahap wawancara, penulis mewawancarai salahsatu perwakilan dari seluruh RT yang bernama Bapak. Sudarto, untuk mendapatkan informasi secara transparan berkaitan dengan kegiatan warga, pendataan kependudukan, mengelola iuran warga, serta proses surat-menyurat.

3) Study Pustaka(Library Research): Dengan mempelajari dan menganalisa permasalahan yang berhubungan dengan proses penyimpanan data, kegiatan informasi iuran warga, dan pendataan warga yang masih manual. Dalam proses pembelajaran ini, penulis melakukan kajian dari berbagai sumber pustaka baik berupa buku, jurnal ilmiah, serta media elektronik.

\section{B. Metode Penelitian}

Penelitian dilakukan dengan menganalisa dan mengumpulkan data-data pada proses informasi pelayanan untuk memudahkan warga. Dalam pengembangan sistem menggunakan metode "SDLC (Systems Development Life Cycle)" merupakan gambaran dalam merancang sebuah sistem yang akan melakukan langkah-langkah atau tahapan [4]. Dengan menggunakan metode "SDLC (Systems Development Life Cycle)" teknik waterfall yang sangat tepat untuk melakukan tahap-tahap secara berurutan. Motode pengembangan sistem dalam perancangan ini menggunakan model pengembangan sistem informasi yang sistematis yaitu waterfall. Metode waterfall merupakan metode yang dilakukan seorang sistem analisa dalam pengerjaan yang dilakukan secara berurutan untuk menyelesaikan tahap - tahapan tanpa mengulangi kembali tahapan tersebut [5]. Pada tahun

1970 model waterfall pertama kali diperkenalkan oleh Winston Royce yang menggambarkan pendekatan yang 
sistematis dan berurutan pada pengembangan perangkat lunak [6].

Dalam pengembangan sistem teknik SDLC (System Develompent Life Cycle) pada setiap langkah mempunyai tujuan yang mendukung penyusunan sistem secara efisien dan efektif [4]. Waterfall disebut sebagai air terjun kebawah yang melewati fase fase perencanaan, permodelan, implementasi dan pengujian. Sebuah metode yang bisa dilakukan untuk membuat pembaruan sistem yang berjalan.

Bahasa pemrograman dalam PHP kependekan dari Personal Home Page merupakan PHP Hypertext Preprocessor yang pertama kali dibuat Rasmus Lerdof tahun 1994, sebuah bahasa pemrograman web yang bersifat Open Source berbasis server-side yang dapat disisipkan pada halaman HTML untuk menghasilkan tampilan yang dinamis [7]. PHP bersifat interpreter yaitu bekerja dengan menterjemahkan intruksi saat program dimulai [8]. HTML merupakan kependekan dari (HyperText Markup Language) yaitu bahasa markup yang digunakan dalam perintah kode program yang digunakan programmer web professional untuk menampilkan informasi beruba teks, grafik, serta multimedia yang berhubungan dengan tampilan web page (hyperlink) [9].

Memanfaatkan basisdata dalam kebutuhan sistem. Basis data merupakan sekumpulan data-data yang diorganisasikan dalam bentuk skema serta struktur yang saling berhubungan. Untuk mengelola dan memanipulasi sebuah data yang disimpan di dalam hardware komputer, dibutuhkan sebuah software yang mendukung seperti Mysql [10]. MySQL (My Structured Query Language) merupakan sebuah perangkat lunak sistem manajemen data SQL atau DBMS yang terdiri dari jumlah table dan beberapa column data yang saling berhubungan yang telah dikembangkan dalam suatu organisasi dan hak cipta dari penulisnya [9]. PhpMyAdmin merupakan sebuah perangkat lunak yang digunakan untuk mengelola administrasi database berupa basis data, tabel-tabel, serta relasi pengguna dalam mengatur data pada MySql [11].

Memanfaatkan kerangka kerja Framework merupakan kerangka kerja untuk memudahkan para developer dalam membuat dan mengembangkan sebuah aplikasi. Framework berisikan perintah fungsi dasar yang tersusun dan terstrukrur. Salah satu framework tersebut menggunakan framework PHP yang menerapkan sebuah konsep MVC (Model-View-Controller). MVC merupakan konsep pengembangan software yang menerapkan arsitektur model sebagai struktur data yang berisikan fungsi kode yang berhubungan dengan basisdata, view sebagai tampilan kepada pengguna, dan controller sebagai jembatan antara model dan view [12].

Dalam kerangka kerja yang menggunakan konsep MVC adalah Laravel merupakan kerangka kerja aplikasi web berbasis PHP yang menggunakan konsep MVC, berada dibawah lisensi MIT (Massachusetts Institute of Technology) dengan source code yang sudah disediakan oleh Github yaitu sebuah layanan hos web

bersama untuk proyek pengembangan perangkat lunak [13]. Laravel dibuat oleh Taylor Otwell pada tahun 2011, merupakan framework PHP dengan versi yang up-to-date dengan syarat PHP versi 5,3 keatas. Laravel merupakan konsep (Model-View-Controller) MVC web development framework sebuah kerangka kerja dalam pengembangan sebuah web yang memiliki fitur-fitur dan kelebihan untuk meningkatkan kualitas dan produktifitas development dengan sintak yang tersusun, terstruktur, fungsional, implementasi yang efisien, serta mengurangi biaya pengembangan dan perbaikan [12]. Dengan framework CSS yang menarik menggunakan Bootstrap merupakan framework CSS (Cascading Style Sheet) yang bersifat open source yang dikembangkan oleh Jacob Thornton dan Mark Otto pada awal mulanya bernama Twitter Blueprint atau Boostrap Twitter. Dengan menggunakan bootstrap memudahkan para pengembangan website atau developer untuk merancang serta mengatur tampilan layout kerangka kerja yang berisi templat desain berbasis HTML (HyperText Markup Language) dan CSS (Cascading Style Sheet) pada halaman website yang akan diakses oleh pengguna, sehingga menghasilkan tampilan desain yang menarik dan responsif [14].

\section{HASIL DAN PEMBAHASAN}

\section{A. Analisa Kebutuhan Software}

Dalam proses pengembangan sebuah software untuk menganalisa berbagai kebutuhan seperti input dan output yang dibutuhkan admin RW dengan user interface yang menarik serta memudahkan user untuk digunakan dan dipahami. Dengan menggambarkan alur sistem Use Case Diagram dan Activity Diagram. Maka yang dibutuhkan adalah admin RW dan User warga.

Berikut ini kebutuhan Admin RW:

1) RW dapat melakukan login dan logout.

2) RW dapat melihat dan mengetahui notifikasi.

3) RW dapat mengelola data master RT.

4) RW dapat mengelola master kategori.

5) RW dapat mengelola data berita.

6) RW dapat mengelola data gambar.

7) RW dapat mengelola data penduduk.

8) RW dapat mengetahui data iuran warga perRT

9) RW dapat mengelola melihat dan mengetahui data pengajuan surat pengantar.

Berikut ini kebutuhan User Warga

1) User Warga dapat melihat dan mengetahui informasi seputar berita.

2) User Warga dapat melihat dan mengetahui informasi seputar kegiatan.

3) User Warga dapat melihat dan mengetahui informasi profil RT dan RW.

4) User Warga dapat melihat dan mengetahui informasi jenis pelayanan.

5) User Warga dapat membuat dan mencetak surat pengantar.

6) User Warga dapat melihat dan mengetahui daftar data penduduk dan informasi iuran warga perRT.

7) User Warga dapat melihat galeri foto. 


\section{B. Design}

Dalam tahapan design terdapat 3 jenis design sebagai berikut:

1) Design Sistem

\section{- Use Case Diagram}

Use Case Diagram merupakan tampilan diagram yang menggambarkan interaksi antara pengguna dengan sistem yang telah dibuat.

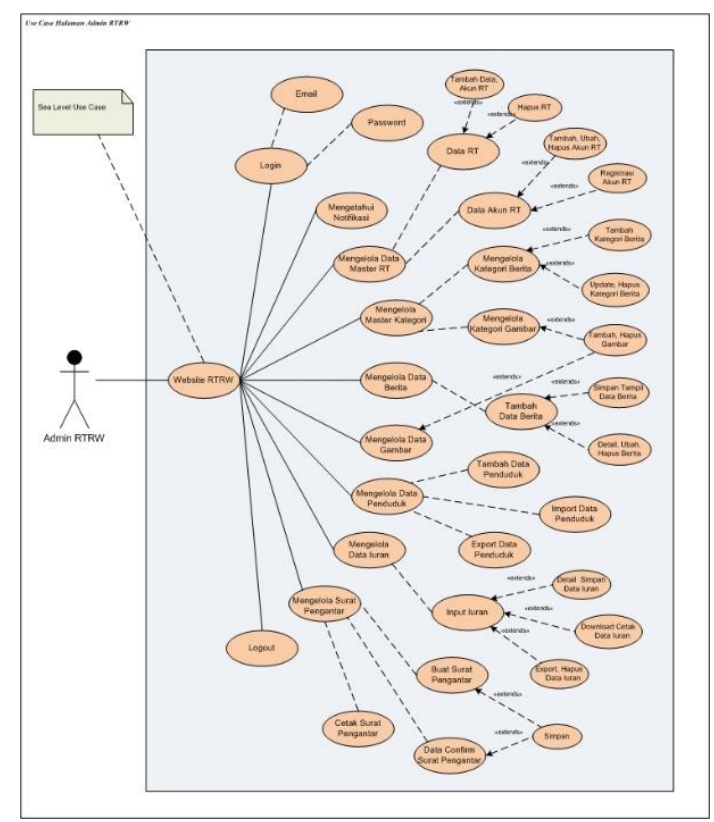

Gambar 1. Use case diagram admin RW

Terdapat Use Case Diagram Admin RW dan Use Case Diagram User Warga.

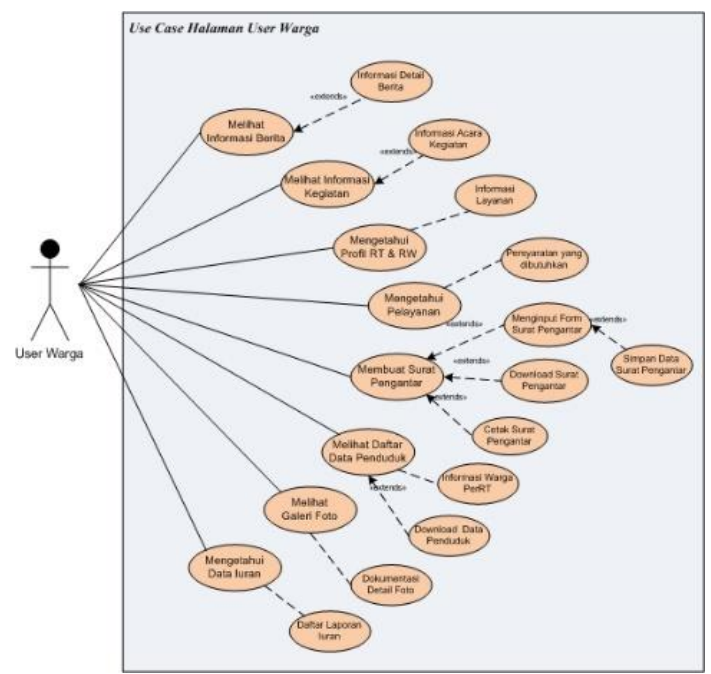

Gambar 2. Use case diagram User Warga

\section{- Activity Diagram}

Activity Diagram merupakan tampilan diagram yang digunakan untuk memberikan fungsi dari sebuah sistem. Activity Diagram memberikan sebuah fungsional dari prosedur kerja dengan menunjukkan diagram aliran pada proses bisnis serta jalur kerja pada system.

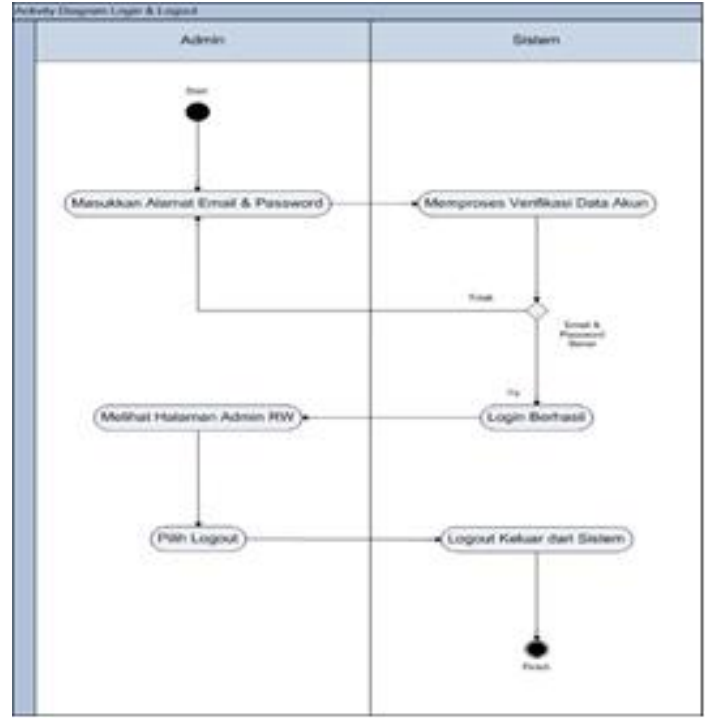

Gambar 3. Activity diagram login dan logout admin

Setelah Activity Diagram Login terdapat Activity Diagram mengelola master kategori informasi.

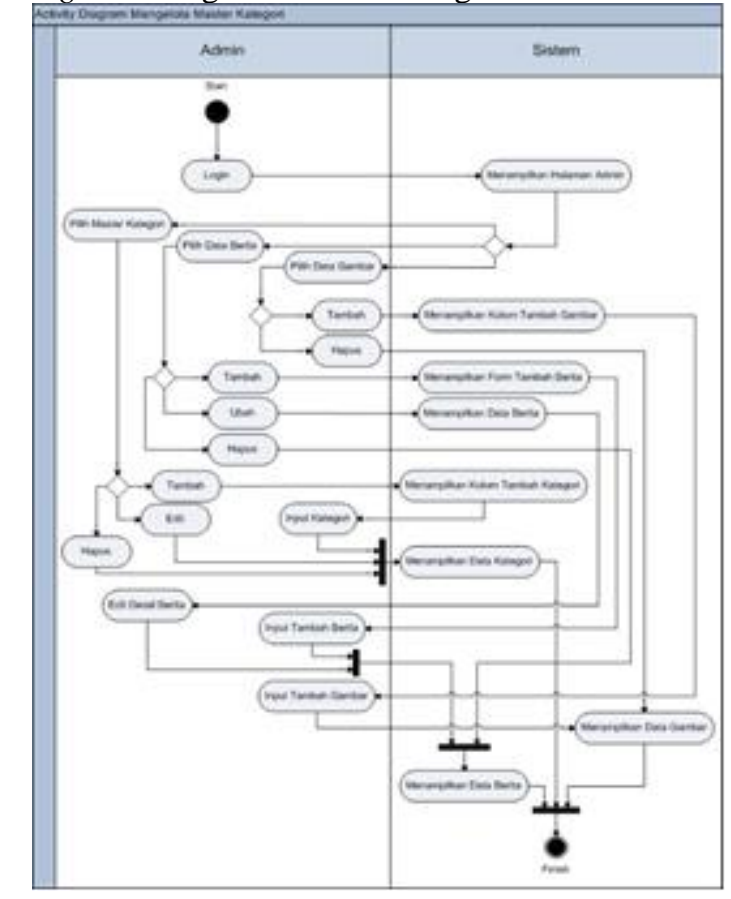

Gambar 4. Activity diagram mengelola master kategori informasi

- Sequence Diagram

Sequence Diagram merupakan tampilan gambaran interaksi antara objek didalam dan disekitar sistem dengan menggambarkan rangkaian langkah-langkah terhadap waktu untuk menunjukkan pesan dan menghasilkan output tertentu. 


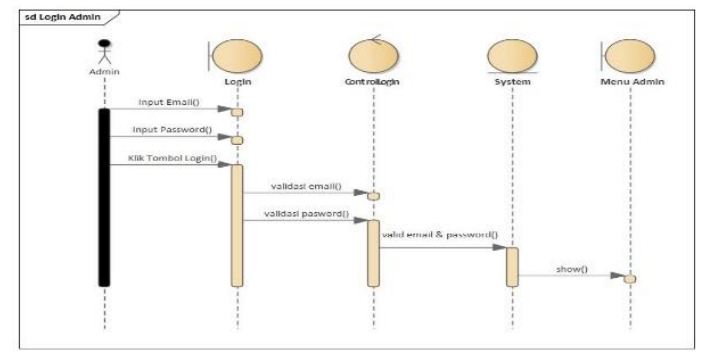

Gambar 5. Sequence diagram login

Sequence Diagram pada mengelola kategori informasi untuk warga.

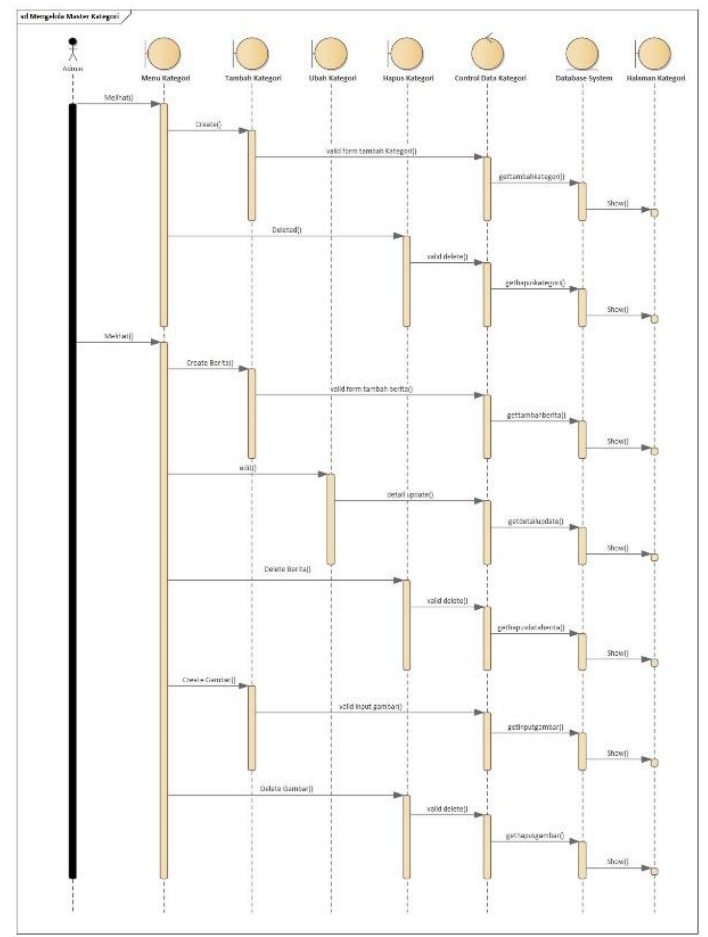

Gambar 6. Sequence diagram mengelola kategori informasi

2) Design Database

Dalam proses pengembangan basis data ERD juga merupakan permodelan data yang konseptual untuk membantu menentukan hubungan antar entitas.

Dalam perancangan design database menggunakan ERD dan LRS. ERD (Entity Relation Diagram) merupakan suatu model yang menggambarkan beberapa notasi dan simbol yang mempunyai hubungan dan relasi dalam basis data yang berdasarkan objek dasar data tersebut [10]. Sedangkan LRS (Logical Record Structure) merupakan struktur record pada tabel yang dihasilkan dari permodelan Entity Relation Ship (ER) beserta atributnya membentuk hasil hubungan antar entitas [7].
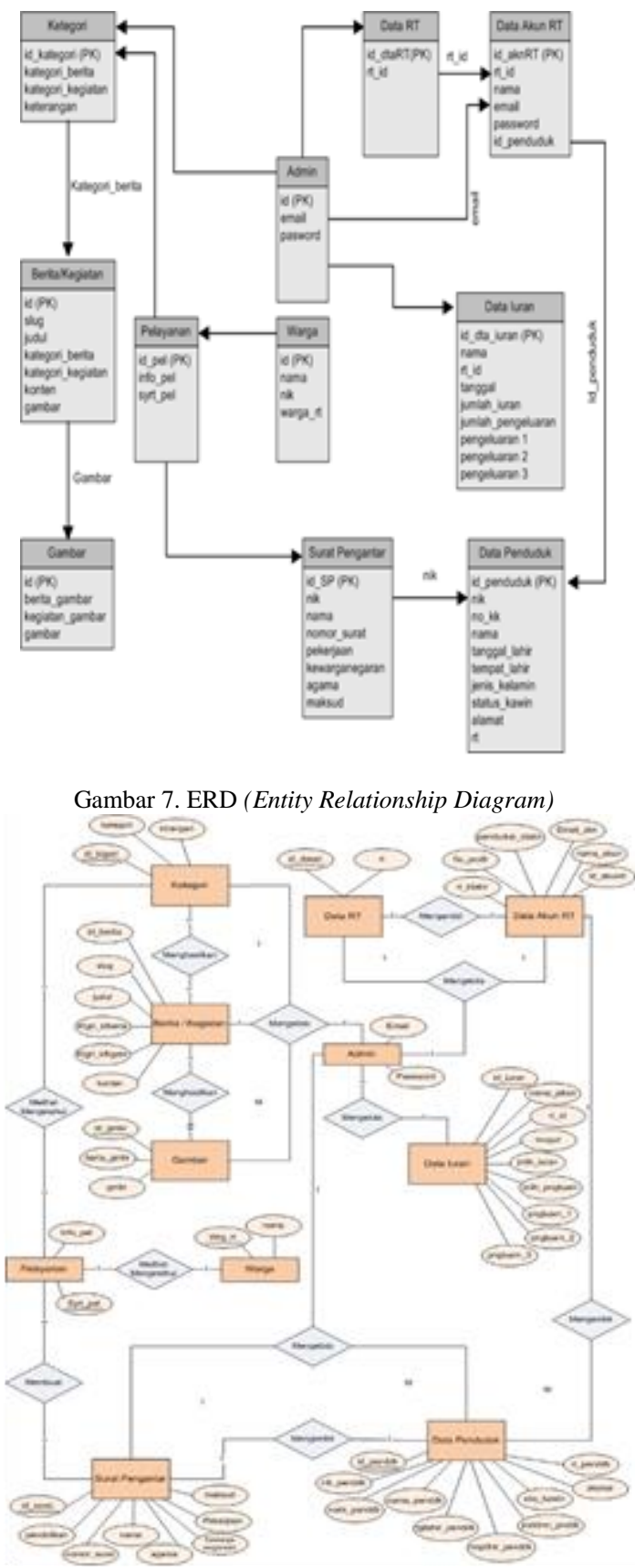

Gambar 8. LRS (Logical Record Structure)

3) Design User Interface

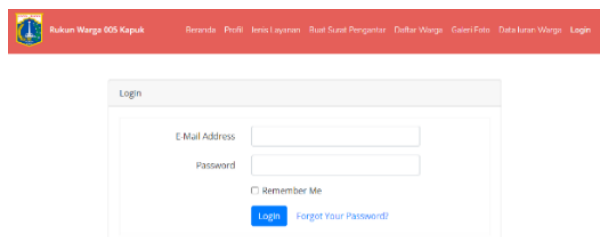

Gambar 9. User Interface Login 


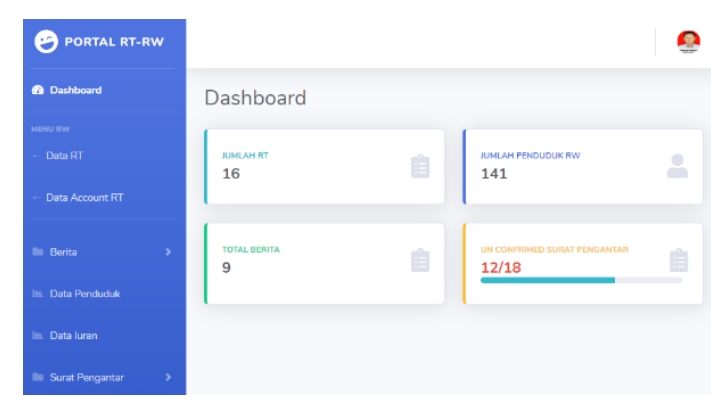

Gambar 10. Halaman Notifikasi

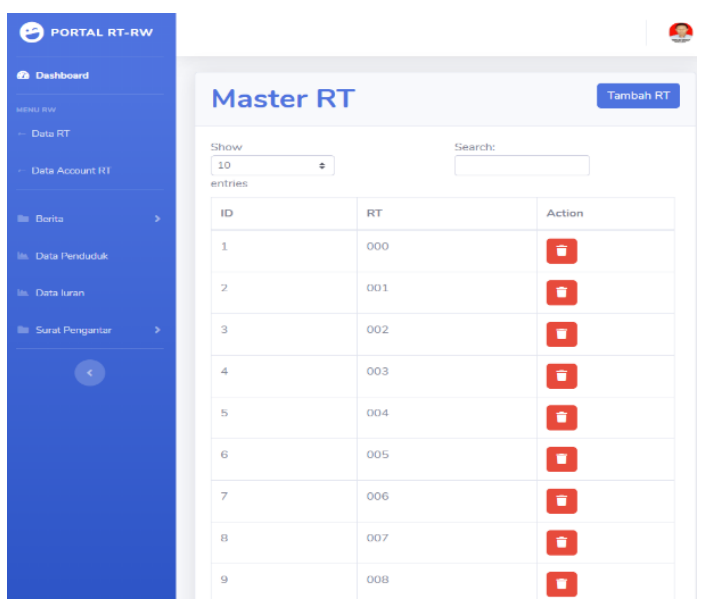

Gambar 11. Halaman Data RT

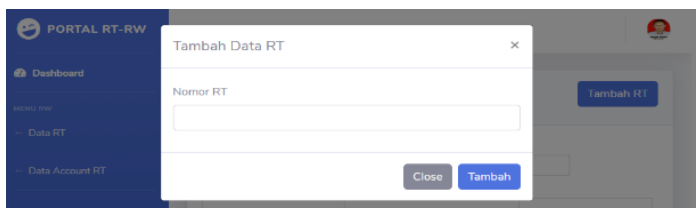

Gambar 12. Halaman Tambah Data RT

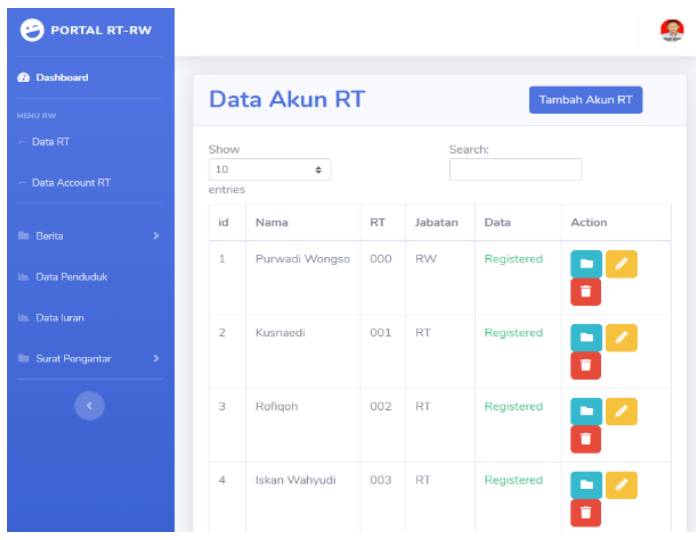

Gambar 13. Halaman Data Akun RT

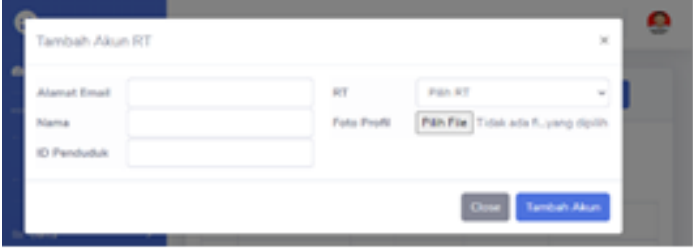

Gambar 14. Halaman Tambah Akun RT

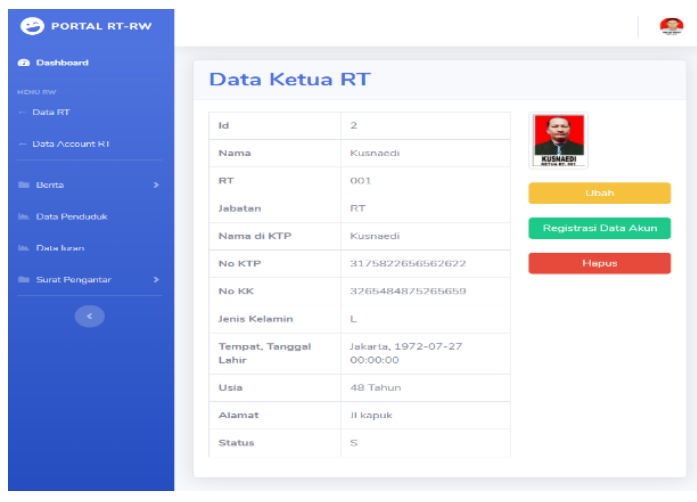

Gambar 15. Halaman Detail Data RT

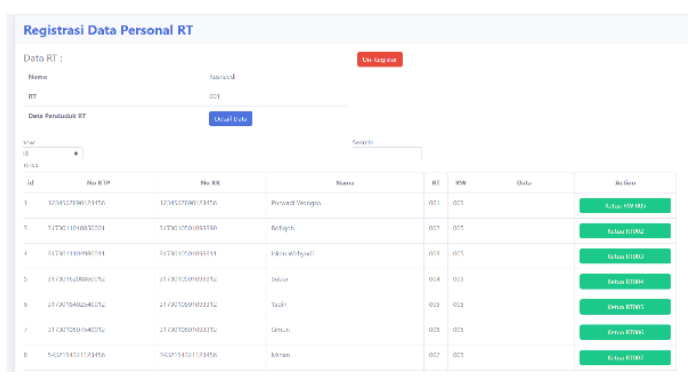

Gambar 16. Registrasi Data Personal RT

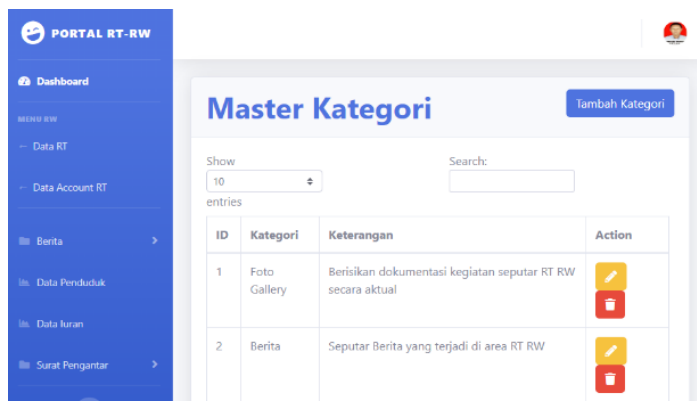

Gambar 17. Master Kategori 


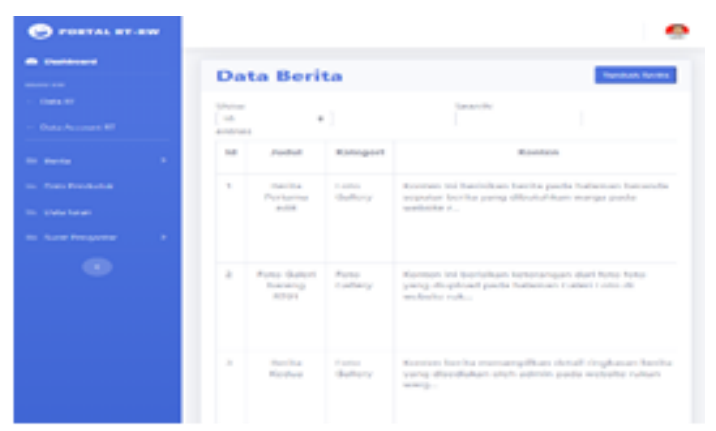

Gambar 18. Data Informasi Berita

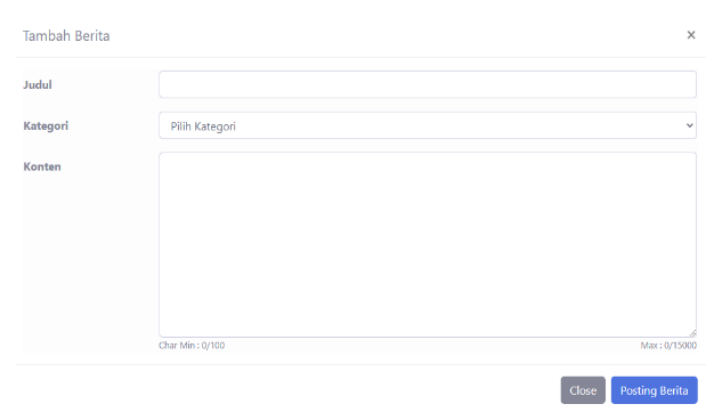

Gambar 19. Form Tambah Berita

Tambah Gambar

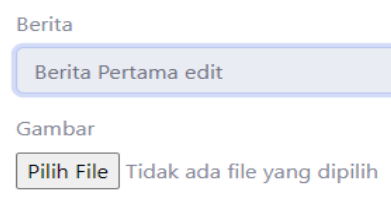

\section{Close Tambah}

Gambar 20. Halaman Tambah gambar

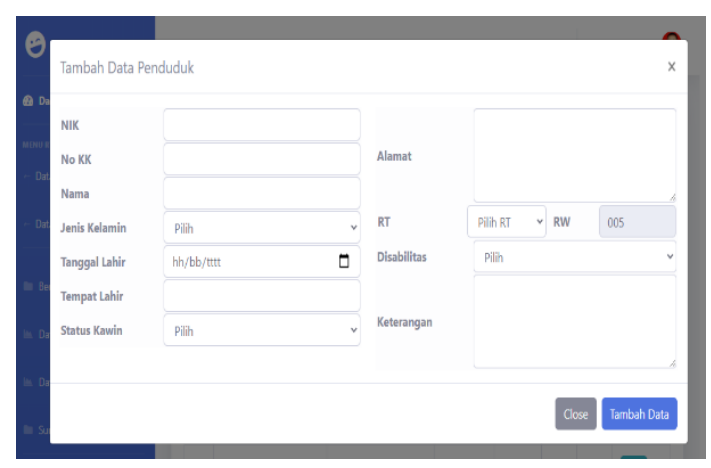

Gambar 21. Form tambah penduduk

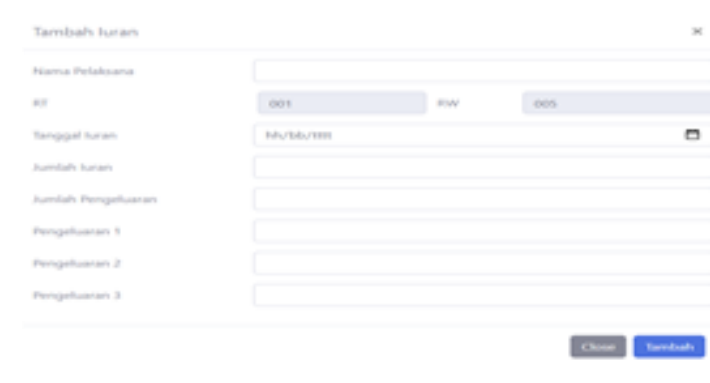

Gambar 22. Form tambah data iuran

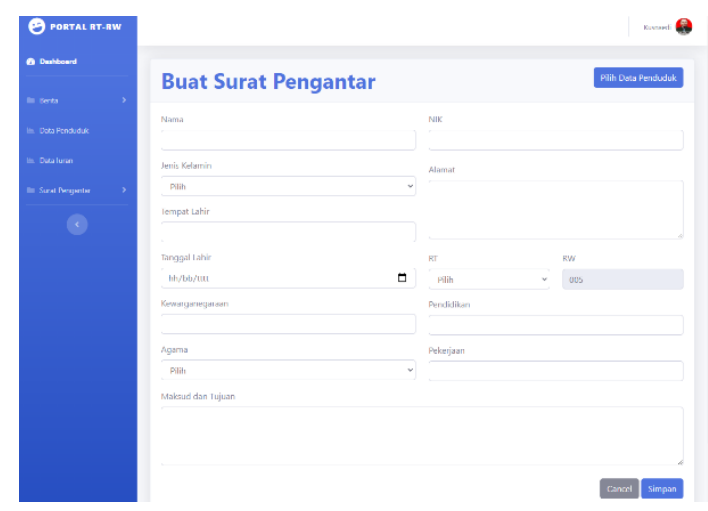

Gambar 23. Form Surat Pengantar

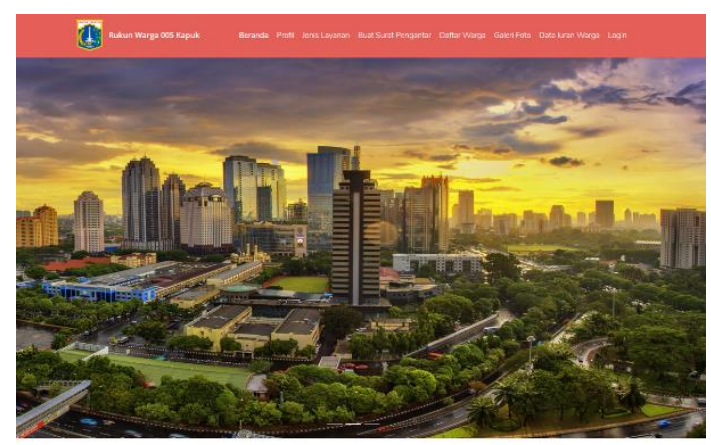

Seputar Berita
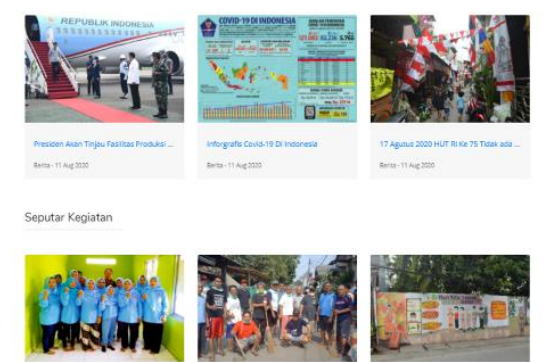

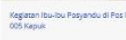

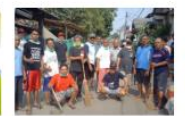

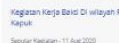

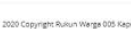

Gambar 24. Halaman Beranda 


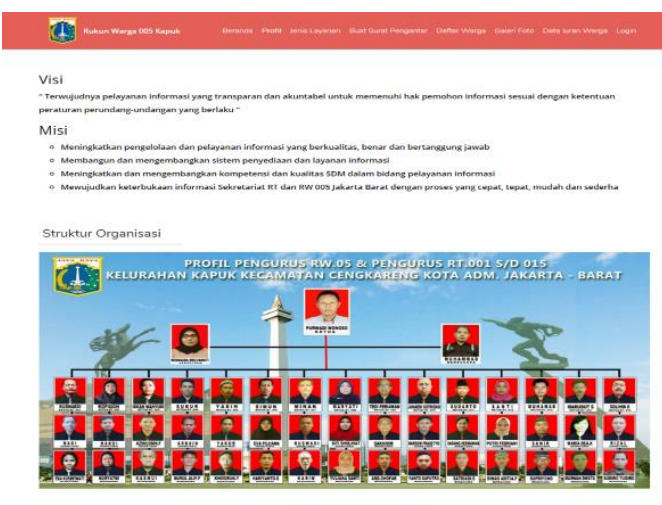

Gambar 25. Halaman Profil RW

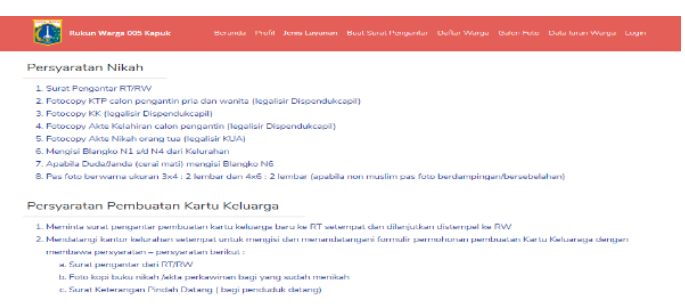

Gambar 26. Halaman Jenis Pelayanan

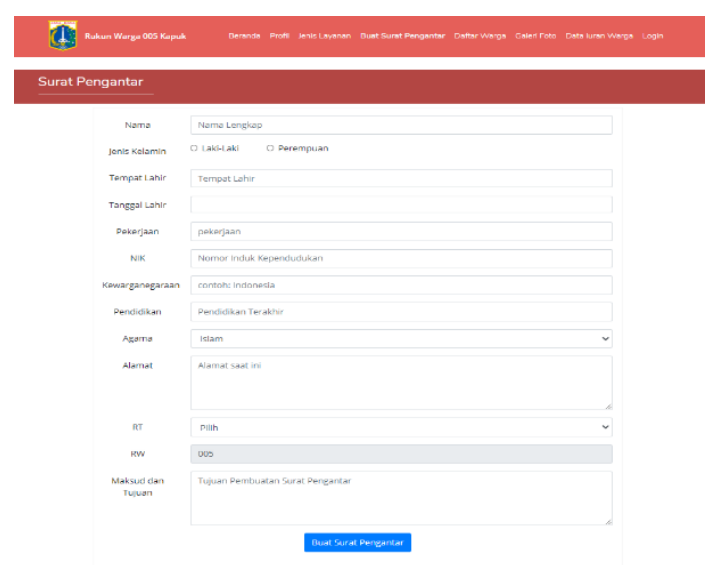

Gambar 27. Halaman Buat Surat Pengantar

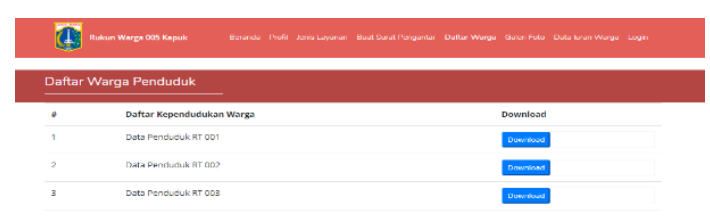

Gambar 28. Halaman Daftar Warga

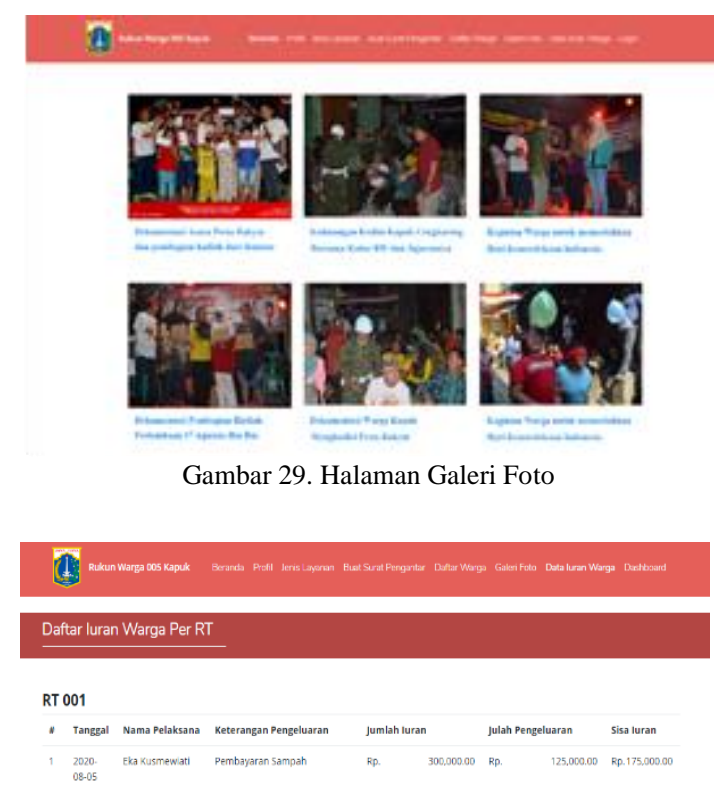

Gambar 30. Halaman Data Iuran Warga PerRT

C. Testing

Dalam tahap pengujian dengan Black-box Testing sebagai metode dalam memastikan sistem berjalan dan bebas dari kesalahan.

TABEL I

HASIL PENGUJIAN BLACK BOX TESTING FORM LOGIN

\begin{tabular}{|c|c|c|c|c|c|}
\hline No & $\begin{array}{l}\text { Skenario } \\
\text { Pengujia } \\
\text { n }\end{array}$ & $\begin{array}{l}\text { Test } \\
\text { Case }\end{array}$ & $\begin{array}{l}\text { Hasil yang } \\
\text { Diharapka } \\
\text { n }\end{array}$ & $\begin{array}{l}\text { Hasil } \\
\text { Pengujia } \\
\text { n }\end{array}$ & $\begin{array}{c}\text { Kesimpu } \\
\quad \text { lan }\end{array}$ \\
\hline 1 & $\begin{array}{l}\text { Jika } \\
\text { email } \\
\text { address } \\
\text { dan } \\
\text { password } \\
\text { kosong, } \\
\text { klik } \\
\text { tombol } \\
\text { login }\end{array}$ & $\begin{array}{l}1 . \\
\text { Email } \\
\text { addres } \\
\text { s: } \\
\text { kosong } \\
\text { 2.Pass } \\
\text { word: } \\
\text { kosong }\end{array}$ & $\begin{array}{l}\text { Sistem akan } \\
\text { menolak, } \\
\text { menampilk } \\
\text { an } \\
\text { peringatan } \\
\text { "Harap isi } \\
\text { bidang ini" }\end{array}$ & $\begin{array}{l}\text { Sesuai } \\
\text { Harapan }\end{array}$ & Valid \\
\hline 2 & $\begin{array}{l}\text { Jika } \\
\text { email } \\
\text { address } \\
\text { atau } \\
\text { password } \\
\text { salah, } \\
\text { klik } \\
\text { tombol } \\
\text { login }\end{array}$ & $\begin{array}{l}1 . \\
\text { Email } \\
\text { addres } \\
\text { s: } \\
\text { benar } \\
\text { Passw } \\
\text { ord } \\
\text { salah } \\
2 . \\
\text { Email } \\
\text { addres } \\
\text { s: } \\
\text { salah } \\
\text { Passw } \\
\text { ord: } \\
\text { benar }\end{array}$ & $\begin{array}{l}\text { Sistem akan } \\
\text { menolak. } \\
\text { menampilk } \\
\text { an } \\
\text { peringatan } \\
\text { "These } \\
\text { credentials } \\
\text { do not } \\
\text { match our } \\
\text { records" }\end{array}$ & $\begin{array}{l}\text { Sesuai } \\
\text { Harapan }\end{array}$ & Valid \\
\hline
\end{tabular}




\begin{tabular}{|l|l|l|l|l|l|}
\hline 3 & Email & 1. & Sistem & Sesuai & \\
& address & Email & dapat & Harapan & \\
& dan & addres & mengakses & & \\
& password & $s:$ & dan & & \\
& benar, & benar & menampilk & & Valid \\
& klik & Passw & an halaman & & \\
& tombol & ord: & admin & & \\
& login & benar & & & \\
& & & & & \\
\hline
\end{tabular}

TABEL II

HASIL PENGUJIAN BLACK BOX TESTING FORM TAMBAH RT

\begin{tabular}{|l|l|l|l|l|l|}
\hline No & $\begin{array}{l}\text { Skenar } \\
\text { io } \\
\text { Penguj } \\
\text { ian }\end{array}$ & $\begin{array}{l}\text { Test } \\
\text { Case }\end{array}$ & $\begin{array}{l}\text { Hasil yang } \\
\text { Diharapka } \\
\text { n }\end{array}$ & $\begin{array}{l}\text { Hasil } \\
\text { Pengujia } \\
\text { n }\end{array}$ & $\begin{array}{l}\text { Kesimpu } \\
\text { lan }\end{array}$ \\
\hline 1 & $\begin{array}{l}\text { Jika } \\
\text { tambah } \\
\text { RT } \\
\text { kosong } \\
\text { klik } \\
\text { tambah }\end{array}$ & $\begin{array}{l}\text { Tambah } \\
\text { nomor } \\
\text { RT } \\
\text { kosong }\end{array}$ & $\begin{array}{l}\text { Sistem } \\
\text { akan } \\
\text { menolak, } \\
\text { untuk } \\
\text { mengisi } \\
\text { nomor RT }\end{array}$ & $\begin{array}{l}\text { Sesuai } \\
\text { Harapan }\end{array}$ & Valid \\
\hline 2 & $\begin{array}{l}\text { Jika } \\
\text { input } \\
\text { tambah } \\
\text { nomor } \\
\text { RT } \\
\text { benar, } \\
\text { klik } \\
\text { tambah }\end{array}$ & $\begin{array}{l}\text { Tambah } \\
\text { nomor } \\
\text { RT benar }\end{array}$ & $\begin{array}{l}\text { Sistem } \\
\text { dapat } \\
\text { mengakses } \\
\text { dan } \\
\text { menampilk } \\
\text { an data RT } \\
\text { baru }\end{array}$ & $\begin{array}{l}\text { Sesuai } \\
\text { Harapan }\end{array}$ & Valid \\
& & & \\
& & & & \\
& & & & \\
& & & & \\
\end{tabular}

TABEL III

HASIL PENGUJIAN BLACK BOX TESTING TOMBOL TAMBAH KATEGORI

\begin{tabular}{|l|l|l|l|l|l|}
\hline No & $\begin{array}{l}\text { Skena } \\
\text { rio } \\
\text { Pengu } \\
\text { jian }\end{array}$ & $\begin{array}{l}\text { Test } \\
\text { Case }\end{array}$ & $\begin{array}{l}\text { Hasil yang } \\
\text { Diharapka } \\
\text { n }\end{array}$ & $\begin{array}{l}\text { Hasil } \\
\text { Pengujia } \\
\text { n }\end{array}$ & $\begin{array}{l}\text { Kesim } \\
\text { pulan }\end{array}$ \\
\hline 1 & $\begin{array}{l}\text { Jika } \\
\text { tamba } \\
\text { h } \\
\text { katego } \\
\text { ri } \\
\text { benar } \\
\text { klik } \\
\text { tamba } \\
\text { h } \\
\text { katego } \\
\text { ri }\end{array}$ & $\begin{array}{l}\text { Tambah } \\
\text { kategori } \\
\text { data } \\
\text { berita } \\
\text { gambar } \\
\text { benar }\end{array}$ & $\begin{array}{l}\text { Sistem } \\
\text { akan } \\
\text { menampilk } \\
\text { an kategori } \\
\text { berita } \\
\text { gambar }\end{array}$ & $\begin{array}{l}\text { Sesuai } \\
\text { Harapan }\end{array}$ & Valid \\
& & & \\
& & & \\
\end{tabular}

TABEL IV

HASIL PENGUJIAN BLACK BOX TESTING TOMBOL TAMBAH DATA BERITA

\begin{tabular}{|l|l|l|l|l|l|}
\hline No & $\begin{array}{l}\text { Skenar } \\
\text { io } \\
\text { Penguj } \\
\text { ian }\end{array}$ & $\begin{array}{l}\text { Test } \\
\text { Case }\end{array}$ & $\begin{array}{l}\text { Hasil yang } \\
\text { Diharapka } \\
\text { n }\end{array}$ & $\begin{array}{l}\text { Hasil } \\
\text { Pengujia } \\
\text { n }\end{array}$ & $\begin{array}{l}\text { Kesim } \\
\text { pulan }\end{array}$ \\
\hline
\end{tabular}

\begin{tabular}{|c|c|c|c|c|c|}
\hline 1 & $\begin{array}{l}\text { Jika } \\
\text { salah } \\
\text { satu } \\
\text { tambah } \\
\text { berita } \\
\text { judul, } \\
\text { kategor } \\
\text { i, } \\
\text { konten } \\
\text { salah } \\
\text { kelik } \\
\text { tambah } \\
\text { berita } \\
\end{array}$ & $\begin{array}{l}\text { Tamba } \\
\mathrm{h} \text { berita } \\
\text { judul, } \\
\text { kategor } \\
\mathrm{i}, \\
\text { konten } \\
\text { salah }\end{array}$ & $\begin{array}{l}\text { Sistem } \\
\text { akan } \\
\text { menolak, } \\
\text { untuk } \\
\text { melengkapi } \\
\text { berita }\end{array}$ & $\begin{array}{l}\text { Sesuai } \\
\text { Harapan }\end{array}$ & Valid \\
\hline 2 & $\begin{array}{l}\text { Jika } \\
\text { tambah } \\
\text { berita } \\
\text { judul, } \\
\text { kategor } \\
\text { i, } \\
\text { konten } \\
\text { benar } \\
\text { klik } \\
\text { tambah } \\
\text { berita }\end{array}$ & $\begin{array}{l}\text { Tamba } \\
\text { h berita } \\
\text { judul, } \\
\text { kategor } \\
\text { i, } \\
\text { konten } \\
\text { sesuai }\end{array}$ & $\begin{array}{l}\text { Sistem } \\
\text { akan } \\
\text { menampilk } \\
\text { an data } \\
\text { yang sudah } \\
\text { ditambah }\end{array}$ & $\begin{array}{l}\text { Sesuai } \\
\text { Harapan }\end{array}$ & Valid \\
\hline
\end{tabular}

TABEL V

HASIL PENGUJIAN BLACK BOX TESTING TOMBOL TAMBAH GAMBAR

\begin{tabular}{|l|l|l|l|l|l|}
\hline No & $\begin{array}{l}\text { Skenar } \\
\text { io } \\
\text { Penguj } \\
\text { ian }\end{array}$ & $\begin{array}{l}\text { Test } \\
\text { Case }\end{array}$ & $\begin{array}{l}\text { Hasil yang } \\
\text { Diharapka } \\
\text { n }\end{array}$ & $\begin{array}{l}\text { Hasil } \\
\text { Pengujia } \\
\text { n }\end{array}$ & $\begin{array}{l}\text { Kesim } \\
\text { pulan }\end{array}$ \\
\hline 1 & $\begin{array}{l}\text { Jika } \\
\text { tambah } \\
\text { gambar }\end{array}$ & $\begin{array}{l}\text { tambah } \\
\text { gambar }\end{array}$ & $\begin{array}{l}\text { Sistem } \\
\text { akan } \\
\text { menampilk } \\
\text { an gambar }\end{array}$ & $\begin{array}{l}\text { Sesuai } \\
\text { Harapan }\end{array}$ & Valid \\
\hline 2 & $\begin{array}{l}\text { sesuai } \\
\text { dengan } \\
\text { berita, } \\
\text { klik } \\
\text { tambah } \\
\text { gambar }\end{array}$ & $\begin{array}{l}\text { berita } \\
\text { benar } \\
\text { sesuai }\end{array}$ & $\begin{array}{l}\text { sesuai } \\
\text { dengan } \\
\text { berita }\end{array}$ & & \\
& & & & \\
\end{tabular}

HASIL PENGUJIAN BLACK BOX TESTING TAMBAH DATA PENDUDUK

\begin{tabular}{|c|c|c|c|c|c|}
\hline No & $\begin{array}{l}\text { Skenar } \\
\text { io } \\
\text { Penguj } \\
\text { ian } \\
\end{array}$ & $\begin{array}{l}\text { Test } \\
\text { Case }\end{array}$ & $\begin{array}{l}\text { Hasil yang } \\
\text { Diharapka } \\
\text { n }\end{array}$ & $\begin{array}{l}\text { Hasil } \\
\text { Pengujia } \\
\text { n }\end{array}$ & $\begin{array}{l}\text { Kesimpula } \\
\text { n }\end{array}$ \\
\hline 1 & $\begin{array}{l}\text { Jika } \\
\text { salahsa } \\
\text { tu } \\
\text { pengisi } \\
\text { an } \\
\text { untuk } \\
\text { tambah } \\
\text { data } \\
\text { pendud } \\
\text { uk } \\
\text { salah } \\
\text { atau } \\
\text { kosong }\end{array}$ & $\begin{array}{l}\text { Identit } \\
\text { as data } \\
\text { pendud } \\
\text { uk } \\
\text { salah } \\
\text { atau } \\
\text { kosong }\end{array}$ & $\begin{array}{l}\text { Sistem } \\
\text { akan } \\
\text { menolak, } \\
\text { untuk } \\
\text { melengkapi } \\
\text { form }\end{array}$ & $\begin{array}{l}\text { Sesuai } \\
\text { Harapan }\end{array}$ & Valid \\
\hline
\end{tabular}




\begin{tabular}{|l|l|l|l|l|l|}
\hline 2 & Jika & Identit & Sistem & Sesuai & Valid \\
& pengisi & as data & akan & Harapan & \\
an & pendud & menampilk & & \\
& untuk & uk & an untuk & & \\
tambah & benar & data & & \\
data & & penduduk & & \\
pendud & & baru & & \\
uk & & & & \\
benar & & & & \\
dan & & & & \\
lengka & & & & \\
p & & & & \\
\hline
\end{tabular}

TABEL VII

HASIL PENGUJIAN BLACK BOX TESTING TAMBAH DATA IURAN

\begin{tabular}{|c|c|c|c|c|c|}
\hline No & $\begin{array}{l}\text { Skenar } \\
\text { io } \\
\text { Penguj } \\
\text { ian }\end{array}$ & $\begin{array}{l}\text { Test } \\
\text { Case }\end{array}$ & $\begin{array}{l}\text { Hasil yang } \\
\text { Diharapka } \\
\text { n }\end{array}$ & $\begin{array}{l}\text { Hasil } \\
\text { Pengujia } \\
\text { n }\end{array}$ & $\begin{array}{l}\text { Kesimpu } \\
\text { lan }\end{array}$ \\
\hline 1 & $\begin{array}{l}\text { Jika } \\
\text { salahsa } \\
\text { tu } \\
\text { pengisi } \\
\text { an } \\
\text { tambah } \\
\text { data } \\
\text { iuran } \\
\text { kosong } \\
\text { klik } \\
\text { tambah } \\
\text { iuran }\end{array}$ & $\begin{array}{l}\text { Tambah } \\
\text { Iuran } \\
\text { kosong }\end{array}$ & $\begin{array}{l}\text { Sistem } \\
\text { akan } \\
\text { menolak, } \\
\text { untuk } \\
\text { mengisi } \\
\text { data }\end{array}$ & $\begin{array}{l}\text { Sesuai } \\
\text { Harapan }\end{array}$ & Valid \\
\hline 2 & $\begin{array}{l}\text { Jika } \\
\text { tambah } \\
\text { iuran } \\
\text { benar } \\
\text { dan } \\
\text { lengka } \\
\mathrm{p} \\
\text { klik } \\
\text { tambah } \\
\text { iuran }\end{array}$ & $\begin{array}{l}\text { Tambah } \\
\text { Iuran } \\
\text { benar }\end{array}$ & $\begin{array}{l}\text { Sistem } \\
\text { akan } \\
\text { menampilk } \\
\text { an form } \\
\text { tambah }\end{array}$ & $\begin{array}{l}\text { Sesuai } \\
\text { Harapan }\end{array}$ & Valid \\
\hline
\end{tabular}

TABEL VIII

HASIL PENGUJIAN BLACK BOX TESTING BUAT SURAT PENGANTAR

\begin{tabular}{|l|l|l|l|l|l|}
\hline No & $\begin{array}{l}\text { Skenar } \\
\text { io } \\
\text { Penguj } \\
\text { ian }\end{array}$ & $\begin{array}{l}\text { Test } \\
\text { Case }\end{array}$ & $\begin{array}{l}\text { Hasil yang } \\
\text { Diharapka } \\
\text { n }\end{array}$ & $\begin{array}{l}\text { Hasil } \\
\text { Pengujia } \\
\text { n }\end{array}$ & $\begin{array}{l}\text { Kesimpu } \\
\text { lan }\end{array}$ \\
\hline 1 & $\begin{array}{l}\text { Jika } \\
\text { salah } \\
\text { satu } \\
\text { pengisi } \\
\text { an } \\
\text { form } \\
\text { data } \\
\text { surat } \\
\text { pengan } \\
\text { tar } \\
\text { kosong } \\
\text { atau } \\
\text { salah }\end{array}$ & $\begin{array}{l}\text { Input } \\
\text { pengantar } \\
\text { salah }\end{array}$ & $\begin{array}{l}\text { Sistem } \\
\text { akan } \\
\text { menolak, } \\
\text { dan } \\
\text { mengulang } \\
\text { input data } \\
\text { pada form }\end{array}$ & $\begin{array}{l}\text { Sesuai } \\
\text { Harapan }\end{array}$ & Valid \\
\\
$\begin{array}{l}\text { Jika } \\
\text { buat } \\
\text { surat } \\
\text { pengan }\end{array}$ & $\begin{array}{l}\text { Input } \\
\text { data surat } \\
\text { pengantar } \\
\text { lengkap }\end{array}$ & $\begin{array}{l}\text { Sistem } \\
\text { akan } \\
\text { memproses } \\
\text { simpan dan }\end{array}$ & $\begin{array}{l} \\
\text { Sesuai } \\
\text { Harapan }\end{array}$ & \\
\hline
\end{tabular}

\begin{tabular}{|c|c|c|c|c|c|}
\hline & $\begin{array}{l}\text { tar } \\
\text { lengka } \\
\text { p dan } \\
\text { benar }\end{array}$ & & $\begin{array}{l}\text { dapat } \\
\text { download } \\
\text { data surat } \\
\text { pengantar } \\
\text { yang sudah } \\
\text { dibuat }\end{array}$ & & \\
\hline 3 & $\begin{array}{l}\text { Jika } \\
\text { buat } \\
\text { surat } \\
\text { pengan } \\
\text { tar } \\
\text { dengan } \\
\text { pilih } \\
\text { data } \\
\text { pendud } \\
\text { uk } \\
\text { yang } \\
\text { sudah } \\
\text { tersedi } \\
\text { a, klik } \\
\text { pilih } \\
\text { data } \\
\text { pendud } \\
\text { uk }\end{array}$ & $\begin{array}{l}\text { Pilih data } \\
\text { penduduk } \\
\text { sesuai }\end{array}$ & $\begin{array}{l}\text { Sistem } \\
\text { akan } \\
\text { menampilk } \\
\text { an daftar } \\
\text { data } \\
\text { penduduk } \\
\text { dan } \\
\text { otomatis } \\
\text { form terisi } \\
\text { sesuai data } \\
\text { yang sudah } \\
\text { tersedia }\end{array}$ & $\begin{array}{c}\text { Sesuai } \\
\text { Harapan }\end{array}$ & Valid \\
\hline
\end{tabular}

\section{KESIMPULAN}

Berdasarkan pembahasan mengenai pembuatan perencanaan sistem informasi pelayanan Rukun Tetangga dan Rukun Warga Kapuk 005 Berbasis Website, penulis memberikan kesimpulan sebagai berikut:

1. Penggunaan website sistem informasi pelayanan Rukun Tetangga dan Rukun Warga 005 Kapuk, diharapkan dapat memudahkan warga dalam mendapatkan informasi yang dibutuhkan seputar berita, dan kegiatan yang diadakan RT RW.

2. Sistem informasi pelayanan RT dan RW diharapkan dapat membantu RT dan RW mengelola data penduduk dengan penyimpanan ke dalam sistem database dan surat menyurat yang sebelumnya menggunakan tulis tangan manual, kini dengan mudah membuatnya menjadi lebih efektif dan efisien.

3. Sistem informasi pelayanan RT dan RW yang dirancang memudahkan dalam mengelola administrasi data iuran secara terbuka dan transparan dalam bentuk laporan bulanan, untuk menghindari kesalahpahaman dalam mengelola iuran warga.

Dengan sistem informasi pelayanan yang tersampaikan dengan baik kepada masyarakat dan warganya dalam memperkenalkan kepengurusan RT dan RW sehingga akan mempererat tali silaturahmi, kerukunan, dan kekeluargaan.

\section{DAFTAR PUSTAKA}

[1] R. Akbar, E. R. Nainggolan, and S. N. Khasanah, "Sistem Informasi Pelayanan Warga RW 01 Kelurahan Rawa Buaya Berbasis Website," J. Teknol. Sist. Inf. dan Apl., vol. 2, no. 3, p. 99, 2019, doi: 10.32493/jtsi.v2i3.3254.

[2] P. Krisnayani, I. K. R. Arthana, and I. G. M. Darmawiguna, "Analisa Usability Pada Website Undiksha Dengan Menggunakan Metode Heuristic Evaluation," KARMAPATI (Kumpulan Artik. Mhs. Pendidik. Tek. Inform. ISSN 2252-9063, vol. 5 , no. 2, 2016 . 
[3] W. D. Septiani, "Sistem Informasi Pengelolaan Data Penduduk (Studi Kasus: RT/RW Kelurahan Pondok Kacang Timur)," $J$. Ilmu Pengetah. Dan Teknol. Komput., vol. 4, no. 1, pp. 23-28, 2018.

[4] D. Abdullah, Merancang Aplikadi Perpustakaan Menggunakan SDLC, vol. 7, no. 9. 2015.

[5] D. Puastuti and K. S. Abb, "Perancangan Sistem Informasi Pendataan Warga Sekolah Berbasis Web Pada Sdn 2 Pagelaran," Jpgmi, vol. 3, no. 1, pp. 26-42, 2017.

[6] A. Fathoroni, R. N. S. Fatonah, R. Andarsyah, and N. Riza, "Buku Tutorial Sistem Pendukung Keputusan Penilian Kinerja Dosen Menggunakan Metode 360 Degree Feedback." pp. 1920, 2020.

[7] I. Rusdi and M. A. Mashabi, "Sistem Informasi Kependudukan di Rukun Tetangga 04 / 08 Kelurahan Utan Panjang Berbasis Web," J. Sist. Inf. Stmik Antar Bangsa, vol. 12550, no. 1, pp. 9-15, 2017.

[8] Elgamar, Konsep Dasar Pemrograman Website Dengan Php. 2016.

[9] M. Tabrani and E. Pudjiarti, "ANALISIS SISTEM AKUNTANSI PENGGAJIAN DAN PENGUPAHAN KARYAWAN DALAM UPAYA MENDUKUNG PENGENDALIAN INTERN (Studi pada PT.Wonojati Wijoyo Kediri)," J. Adm. Bisnis S1 Univ. Brawijaya, vol. 34, no. 1, pp. 189-196, 2016.

[10] D. Puspitasari, "Rancang Bangun Sistem Informasi Koperasi Simpan Pinjam Karyawan Berbasis Web," J. Pilar Nusa Mandiri, vol. XI, no. 2, pp. 186-196, 2016, [Online]. Available:

http://ejournal.nusamandiri.ac.id/ejurnal/index.php/pilar/article /view/152.

[11] R. E. Standsyah and I. S. R. N.S, "IMPLEMENTASI PHPMYADMIN PADA RANCANGAN SISTEM PENGADMINISTRASIAN," UJMC, Vol. 3, Nomor 2, Hal. 38 - 44 pISSN 2460-3333 eISSN 2579-907X IMPLEMENTASI, vol. №3, p. c. 30, 2017.

[12] A. Z. Muchtar and S. Munir, "Perancangan Web E-Commerce Umkm Restoran Bakso Arema Menggunakan Framework Laravel," vol. 5, no. 1, pp. 26-33, 2019.

[13] Aminudin, Cara Efektif Belajar Framework Laravel. 2015

[14] R. Kaban, DESIGN WEBSITE RESPONSIVE DENGAN BOOTSTRAP. 2017. 